\title{
3 Job and Heroic Virtue
}

Like Boethius, who made the classical epic narratives both a means and an expression of human selfknowledge, the late antique readers of the Book of Job discovered in it a philosophical mirror of the truth of human nature. According to this reading, the book's subject is its hero, Job, a man (vir) living in the land of Hus, who was a true man (Job 1:1: "et erat ille homo verus") by virtue of his likeness to God. ${ }^{1}$ As we have seen, Boethius, under the tutelage of Lady Philosophy, begins his mental journey by defining himself incorrectly as a mortal and rational animal (I.p6, 1 5: "rationale animal atque mortale") and nothing more. ${ }^{2}$ Saint John Chrysostom begins his fourth-century Greek commentary on Job with the same definition of human nature ("A $\nu \theta \rho \omega \pi o ́ s ~ \dot{\varepsilon} \sigma \tau \iota \zeta \hat{\omega} o \nu$

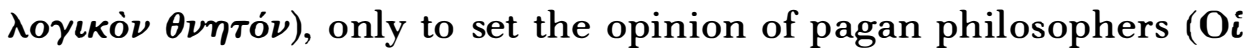
$\mu \varepsilon \dot{\nu} \varepsilon \ddot{\xi} \omega \theta \varepsilon \nu \sigma o \varphi o i)$ in opposition to the scriptural definition of a human being as someone who preserves his essential similitude to God through the practice of virtue. ${ }^{3}$ The Joban expression "true man" (homo verus) is, according to Chrysostom, a biblical homonym. ${ }^{4}$ Job is "true" not only because he is honest in his temporal dealings, but also because he has safeguarded the timeless divine image in which he was created.

Chrysostom's philosophical focus on the vir and homo named in

1. Unlike the Old Latin translation "homo verus," the Vulgate reads "vir simplex."

2. Boethius, De consolatione philosophiae, ed. Ludovicus Bieler, CCSL 94 (Turnhout: Brepols, 1957).

3. Saint John Chrysostom, "Fragmenta in beatum Job," PG 64, c509.

4. Ibid., c511. 
the opening lines of the Book of Job parallels exegetical treatments of the vir mentioned at the opening of Virgil's Aeneid: "Arma virumque cano" (Aen. 1.1). As we have seen, by the early sixth century the historical tendency to read epic as a moral and metaphysical allegory of the self was so entrenched in the schools that when the mythographer Fulgentius asks a personified Virgil to explicate in his own work the "things that schoolmasters expound, for monthly fees, to boyish ears" ("quae mensualibus stipendiis grammatici distrahunt puerilibus auscultatibus"), Virgil responds by presenting "the full range of human life" (p. 122) as the allegorical content of the Aeneid. ${ }^{5}$

According to Fulgentius' Virgil, the opening line of the Aeneid announces its hominal subject matter by referring obliquely to the qualities that constitute human perfection: strength of body ("uirtute corporis") and wisdom of mind ("sapientia ingenii"). The phrase "arms and the man," Virgil explains, recalls the power and the wisdom of the perfected human being: "in armis uirtutem, in uiro sapientiam" (p. 87). Although wisdom governs strength, Virgil nevertheless mentions strength first, because, he says, the soul's wisdom unfolds and displays itself in virtuous action: "in uirtute animae sapientia floret" (p. 88). In doing so, Virgil consciously follows the example of Homer who names the wrath of Achilles before Achilles himself and then shows Minerva as personified self-control, grasping Achilles' hair.

In his fictional dialogue, Fulgentius approves Virgil's explanation by citing two scriptural texts: Psalm 1:1, which indicates that the blessed man does not walk in the counsel of the wicked, and 1 Cor. $1: 24$, which celebrates Christ as the power and wisdom of God ("Christum uirtutem et sapientiam cecinit"), on the grounds that his divinity assumed the perfect human condition: "quod perfectum hominis divinitas adsumpsisse uideretur statum" (p. 87).

Saint Gregory the Great (b. 550) cites the same passage from 1 Corinthians in his explanation of the opening line of the Book of Job: "Vir erat in terra Hus nomine Iob" (I.xi.15, p. 31). ${ }^{6}$ Gregory,

5. Fulgentius the Mythographer, trans. Leslie George Whitbread (Columbus: Ohio State University Press, 1971), p. 121 ; Fulgentius, Expositio Virgilianae continentiae secundum philosophos moralis, in Opera, ed. Rudolph Helm (Stuttgart: Teubner, 1898, 1970), p. 86. Subsequent citations are parenthetical.

6. I quote throughout from the standard edition of the Moralia in Job, ed. M. Adriaen, CCSL 1 43, 143A, 143B (Turnhout: Brepols, 1979-85). For an English transla- 
moreover, interprets the Joban line in a two-part manner that parallels the "arms and the man" allegory spelled out by Fulgentius' pedantic Virgil. The name "Job," he says, means dolens (one who sorrows), whereas "Hus" means consiliator (counselor) (I.xi.15, p. 31 ). As a type of Christ, Job valiantly endures the bodily afflictions that foreshadow Christ's passion. At the same time Job inhabits the land of Hus, his heart ruled by wisdom and right judgment. Interpreted thus, both "Job" and "Hus" characterize the elect, because whoever, sorrowing, hastens from present to eternal things, continually abides in a wise state of mind (I.xxv.34, p. 43).

Isidore of Seville (b. 56o) clearly recognized the Virgilian parallel in Gregory's treatment of Job as a strong and wise man. The younger brother of Bishop Leander of Seville, to whom Gregory affectionately dedicated his copious Moralia in Iob (A.D. 595), Isidore classifies the Book of Job as a heroic poem ("heroicum carmen") antedating the Homeric epics. Heroic poems, according to Isidore, recount in the heroic hexameter the affairs and deeds of brave men: "uirorum fortium res et facta narrentur." 7 Although Isidore mentions the metrical and mixed form of heroic poems, he clearly understands the genre to be defined by its subject matter: the strong and wise hero (vir) whose particular story represents the coming-to-perfection, the true nature of a generalized humankind (homo).

According to Isidore, the heroes who are the subjects of such works are literally airy men and worthy of heaven ("viri quasi aerei et coelo digni") on account of their wisdom and fortitude: "propter sapientiam et fortitudinem." Isidore elsewhere defines a hero as a strong and wise man: "vir fortis et sapiens" (Etym. X.A.2, c367). The word, he explains, derives from the name of the Greek goddess Hera who represents the heavenly realm (aer) where heroes ("viros aerios") desire to dwell: "ubi volunt Heroas habitare" (Etym. VIII.xi.98, c325). The hero is strong because he endures adversity (Etym. X.F.99, c377: "fert adversa"); wise, because he discerns the truth of things and their causes through a refined spiritual sense analogous to taste: "dictus a sapore" (Etym. X.S.240, c392).

tion I use St. Gregory the Great, Morals on the Book of Job, 3 vols., trans. anonymous (Oxford: John Henry Parker, 1844-50). Subsequent citations are parenthetical.

7. Isidore of Seville, Etymologiae I.xxxix.9-1 1, PL 82, c1 1 8-19. 
When Isidore emphasizes power and wisdom as heroic virtues, he articulates a critical commonplace. As Ernst Robert Curtius has shown, Homer's Iliad represents the two Heldentugenden in both isolation (old Nestor's wisdom, Achilles' fearless battle lust) and combination (Odysseus' craftiness and courage) to demonstrate "that strength and intelligence in equipoise $(\mathrm{VII}, 288$; II, 202; IX,53) represent the optimum in warrior virtue." 8 Virgil's Aeneid similarly represents the isolated virtues in his Iliadic characters-Latinus ("all sapientia") and Turnus ("all fortitudo")—in order to highlight their combination in the pietas of Aeneas. ${ }^{9}$ After Virgil, as Curtius observes, the polarity between wisdom and fortitude is firmly established as a rhetorical topic and evident as a controlling principle in the works of Statius (Thebaid), Dictys (fourth century, Ephemeris belli Troiani), and Dares (sixth century, De excidio Troiae), as well as the Anglo-Saxon poems Beowulf and Judith. ${ }^{10}$

Both Curtius and Robert E. Kaske note in passing biblical passages that similarly pair the qualities of wisdom and power. The Book of Job, in particular, abounds in passages associating the two virtues. Job himself has "taught many" and "strengthened weary hands" (4.3: "docuisti multos et manus lassas roborasti"). ${ }^{11}$ Job praises God as one so "wise in heart and mighty in strength" (9:4: "sapiens corde est et fortis robore") that no one can resist him. With the Lord, Job says, is "wisdom and strength" (1 2:13: "sapientia et fortitudo"), "strength and wisdom" (1 2:1 6: "fortitudo et sapientia"); "By his power the seas are suddenly gathered together, and his wisdom has struck the proud one" (26:1 2: "in fortitudine illius repente maria congregata sunt et prudentia eius percussit superbum"). Elihu, insisting that no man,

8. Ernst Robert Curtius, European Literature and the Latin Middle Ages, trans. Willard R. Trask, Bollingen Series 36 (London: Routledge and Kegan Paul, 1953), p. 171 .

9. Ibid., p. 173 .

1 o. Ibid., p. 174. For treatments of the Anglo-Saxon poems, see Robert E. Kaske, "Sapientia et Fortitudo as the Controlling Theme of Beowulf," SP 55.3 (1958): 42356; repr. in An Anthology of Beowulf Criticism, ed. Lewis E. Nicolson (Notre Dame: University of Notre Dame Press, 1963), pp. 269-31 1, and Jane Mushabac, "Judith and the Theme of Sapientia et Fortitudo," Massachusetts Studies in English 4 (Spring 1973): 3-12.

1 1. When I quote the Bible independently, not as an intertext in a particular commentary, I use Biblia sacra iuxta Latinam vulgatam versionem (Rome: Vatican, 1951) and the Douay-Challoner translation of the Vulgate. 
including Job, can compare with God or contend with him, declares: "God is high in his strength, and none is like him among the lawgivers" (36:22: "Ecce Deus excelsus in fortitudine sua et nullus ei similis in legislatoribus"); "He is great in strength and in judgment" (37:23: "magnus fortitudine et iudicio"). Job responds to Yahweh's majestic speech out of the whirlwind with a similar praise of divine wisdom and power: "I know that thou canst do all things, and no thought is hid from thee" (42:2: "scio quia omnia potes et nulla te latet cogitatio").

Neither Curtius nor Kaske, however, elaborate on the significance of the scriptural parallels for medieval readers. Indeed, Kaske remarks that the biblical combination of sapientia et fortitudo, particularly frequent in the Sapiential Books and the Book of Job, is "hardly to be thought of as a heroic ideal." ${ }^{12}$ Fulgentius, Gregory, and Isidore, however, explicitly associate biblical wisdom and sapience with heroism and use the scriptural parallels, especially those found in Job, to gloss the truth and falsity of pagan epic. Later, building upon Gregorian exegesis, Saint Thomas Aquinas finds in the Book of Job a biblical analogue of Boethius' Consolation, a threefold mirror of human nature, and an elaboration of heroic virtue as the Stoic, Peripatetic, and Neoplatonic exegesis of myth had defined it. As we shall see, this kind of comparative reading of sacred and profane texts led in the Middle Ages to a gradual redefinition of the heroic ideal through a reconceptualization of its essential components: the hero himself, his fortitude, and his sapience.

\section{The Hero: Vir and Virtus}

In classical and medieval understanding, the heroic man (vir) excells in power (virtus). Cicero derives "virtus" from "vir" and notes that the quality most characteristic of man is strength: "viri autem propria maxime est fortitudo." 13 Isidore, following Cicero, links vir with virtus, observing that strength (vis) is greater in a man than in a

12. Kaske, "Sapientia et Fortitudo," p. 424.

13. Cicero, Tusculan Disputations, trans. J. E. King, Loeb Classical Library (Cambridge: Harvard University Press, 1927, 197 1), II.xviii.43, pp. 194-97. 
woman. ${ }^{14}$ This basic etymological association, as we shall see, underlies and enables a gradual reconceptualization of the hero (vir) and his semidivine status as moral philosophers from Aristotle to Saint Thomas Aquinas unfolded the meaning of virtus and shifted its primary denotation from physical to spiritual power.

Aristotle lays the foundation in the Nicomachean Ethics when he contrasts vice with virtue, unrestraint with self-restraint, and bestiality with its opposite, "Superhuman Virtue, or goodness on a heroic or divine scale." 15 Aristotle finds the "surpassing virtue" that "changes men into gods" exemplified in the "surpassing valour" of Homer's Hector, who seemed even to his father Priam to be not "the son of mortal man, but of a god" (Il. 24.258). Although this particular Homeric citation associates heroic virtue primarily with fortitude and martial prowess, Aristotle goes on to argue that intellectual virtue, more than any other, divinizes a person. Beginning with the crucial distinction between a person's rational and volitional faculties, he distinguishes correspondent intellectual and moral virtues as habitual dispositions tending toward good actions. The intellectual

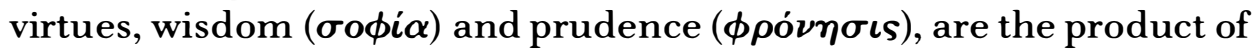
instruction concerning ends and the choice of means to attain ends, whereas the moral virtues, directed by prudence, develop through the practical mastery of pleasure and pain and thus enable the actual achievement of chosen ends. According to Aristotle, the highest virtue, $\sigma o \phi i \alpha$, corresponds to the highest human faculty, the speculative intellect, which as the "ruling and better part" constitutes what is divine in humankind. ${ }^{16}$

Even more than Aristotle, the Stoics associate the divinization of a person with intellectual virtue. Indeed, in their view only the Sage deserves to be called virtuous. As Cicero's Balbus explains it, a special providence shows itself in the gifts of body and soul bequeathed to humankind. Nature raised human beings up from the earth, giving them erect bodies, in order that, beholding the sky, they might gain knowledge of the gods: "ut deorum cognitionem caelum intu-

14. Isidore of Seville, Etym. XI.ii. $17, \mathrm{PL} \mathrm{82,} \mathrm{c}_{4}{ }_{7} 7$.

15. Aristotle, The Nicomachean Ethics, trans. H. Rackham, Loeb Classical Library (London: Heinemann; New York: Putnam, 1926), VII.I, p. 375.

16. Ibid., X.vii.9, p. 619. 
entes capere possent." 17 Thus, he says, the reason of wise men has penetrated into heaven and become identical with the divine ratio governing the fated course of the material universe.

Unlike Aristotle, however, who clearly distinguishes the moral from the intellectual virtues, the Stoics tend to moralize intellectual virtue as a courageous assent to fate-a tendency that mirrors their essentially materialistic identification of the body with the soul, the mind with volition, the world with god, and god with destiny. The Neoplatonists, on the other hand, intellectualize the moral virtues as exemplars. Whereas both the Aristotelian and Stoic approaches to human divinization are essentially anthropocentric-Aristotle defining virtue as a strictly human excellence, the Stoics actually identifying the human with the divine ratio-the Neoplatonist position, as articulated by Plotinus and Macrobius, emphasizes the existence of the cardinal virtues as ideas in the mind of God: "multo magis virtutum ideas esse in mente credendum est." 18 As Macrobius defines them, prudence is the divine mind itself ("mens ipsa divina"); temperance, the unchanging divine intention directed toward God himself; fortitude, divine immutability; justice, the divine governance of works according to eternal law.

According to the Neoplatonists, the civic virtues of prudence, temperance, fortitude, and justice, together with the virtues associated with them, distantly mirror in the social context of human affairs the exemplar virtues that exist in the mind of God: "quae in divina mente consistunt." 19 Practiced in a spirit of detachment from the body and earthly things, the cardinal virtues become purifying virtues that enable the soul's ascent. When the soul is totally directed toward God, the virtues, as practiced by those already purified, take on a perfect, divine quality. As Macrobius notes, as long as the soul inhabits the body, perfect wisdom consists in recognizing the soul's place of origin (and its end): "haec est perfecta sapientia ut, unde orta sit, de quo fonte venerit, recognoscat." 20

17. Cicero, De natura deorum, trans. H. Rackham, Loeb Classical Library (Cambridge: Harvard University Press, 1933, 1979), II.lvi, p. 256.

18. Macrobius, Commentarii in somnivm Scipionis, ed. Jacob Willis (Leipzig: B. G. Teubner, 1970), I.8. 1 o, p. 39. See also Plotinus, "On Virtues," Enneads I.2.6-7, trans. A. H. Armstrong, vol. 1, Loeb Classical Library (Cambridge: Harvard University Press, 1966, 1978).

19. Macrobius, Commentarii, I.8.1 o, p. 39.

20. Ibid., I.9.1-2, p. 40. 
Unlike the Neoplatonist view, the Christian doctrine of deification makes the soul's ascent radically dependent on the divine descent accomplished in Christ's Incarnation and Atoning Sacrifice and sealed by the outpouring of the Holy Spirit. As the scriptures say, the gift of grace makes human beings "children of God" (see John 1:13; 1 John $3: 1,4: 7,5: 1$ ) and actual "partakers of the divine nature" (2 Peter 1:4). ${ }^{21}$ Through the indwelling of the Holy Spirit and the infusion of the theological virtues, faith, hope, and charity, the soul acquires a supernatural likeness to God that extends and perfects the natural, formal likeness evident in the intellectual and volitional faculties. Faith, as a superadded habitus, perfects the intellect by affording it access to revealed truth and intuitive understanding. Supernatural hope supplies what is lacking in the natural will by directing it toward God and divine goods. Charity accomplishes the lasting union between God and human beings, a union that divinizes them.

Christian saints respond to the infused gift of grace with an equally total gift of themselves, directing all their mental and volitional faculties and the acts of all the virtues, intellectual, moral, and theological, toward the love of God. Having received divine life, the saint heroically conforms himself to the pattern of Christ's earthly life, so that, as Saint Paul says, "It is now no longer I that live, but Christ lives in me" (Galatians 2:20).

When, therefore, Saint Thomas Aquinas accepts Aristotle's idea of superhuman or heroic virtue and aligns it with the Plotinian ideal of the perfect virtue of the purified (purgati animi), he does so within a scripturally-informed notion of human personhood and perfection. Citing Christ's command, "You therefore are to be perfect even as your Heavenly Father is perfect" (Matt. 5:48), Aquinas accepts Aristotle's opinion that "it belongs to man to strive as much as possible to attain what is divine" (Q.lxi.Art.5) and applies Plotinus' notion of perfect virtues to Christian saints: "These are the virtues we attribute to the blessed or to those who are most perfect in this life." 22 Aquinas

21. Three main schools of Christian thought interpret these passages on human divinization to mean: (1) the substantial identification of man with God, as posited by Meister Eckhart, Molinos, and the pantheists; (2) the moral union of man with God, as postulated by Luther and Calvin; (3) the ontological transformation of the human person, as understood by Catholic theologians. See the articles on "Divine Nature, Partaker of," "Divine Indwelling," and "Grace" in the New Catholic Encyclopedia.

22. Saint Thomas Aquinas, "Treatise on the Virtues," trans. John A. Oesterle (Englewood Cliffs, N.J.: Prentice Hall, 1966), p. 116. 
then proceeds to discuss the infused theological virtues upon which depends the human attainment of "a happiness surpassing man's nature, which man can arrive at only by the power of God, by a certain participation in divinity (Q.lxii.1). ${ }^{23}$ Thus Aquinas makes the Christian saint answer to the Homeric demigod and prepares the way for the Church's formal acceptance of heroic virtue as an official criterion for canonization. ${ }^{24}$ The saints, like Isidore's "viri quasi aerei" are "worthy of heaven": "coelo digni."

\section{The Hero's Fortitude}

In the Nicomachean Ethics Aristotle distinguishes five kinds of courage: the courage of the citizen-soldier, of experience, of passion, of a sanguinic temperament, of ignorance. ${ }^{25}$ The truest of these, he says, is the citizen's courage, which is publicly displayed on the battlefield and motivated by both the fear of disgrace and the desire for honor. Aristotle pointedly associates courage with personal initiative, a deliberate choice of fearless action, and public occasion. To be fearless of death by drowning or disease does not, in his view, exemplify fortitude. ${ }^{26}$ Rather, fortitude is best illustrated by Homer's heroes in a setting of martial combat.

The Stoics, on the other hand, define fortitude as the subjective constantia of the wise man who steels himself to endure the blows of fortune without fear or pain (apatheia). As Seneca understands it, the difficult circumstances that beset the vir bonus allow him to know himself and display the strength of his mind: "vim animi sui ostenderet." 27 Bad fortune is the adversary that tests men and discovers

23. Ibid., p. 118.

24. The $149^{2}$ canonization of Saint Bonaventure included a formal inquiry into his heroic practice of the three theological and four cardinal virtues. By the time of the Renaissance "heroic virtue" was a technical term for the degree of holiness requisite for beatification or canonization. Prospero Lambertini (later Pope Benedict XIV) composed the standard work on the criteria for canonization: De beatificatione Servorum Dei et de Beatorum canonizatione (Bologna, 1 734-38).

25. Aristotle, Nicomachean Ethics, III.viii, pp. 162-71.

26. See Nicomachean Ethics III.vi.7-9, pp. 156-57.

27. Seneca, "De Providentia," in Moral Essays, vol. 1, trans. John W. Basore, Loeb Classical Library (Cambridge: Harvard University Press, 1958), IV.3, p. 24. Subsequent citations are parenthetical. 
among them a great exemplar (De Prov. III.4, p. 16 ). The assaults of adversity do not weaken the brave man's spirit ("viri fortis animum"), but rather strengthen it (De Prov. II. 1, p. 6).

In this Stoic scenario the true hero is best exemplified not by Homer's combatants but by political prisoners and martyred philosophers like Cato and Socrates (De Prov. III.4, pp. 16-17). Seneca, however, simultaneously exposes the literal falsity of the archaic understanding of courage and underscores its allegorical truth by using epic images to describe the wise man's fortitude. Even as wrestlers ("athletae") willingly struggle with the strongest opponents, knowing that physical strength diminishes without an adversary to test it, so should good men act in their spiritual confrontation with fate (De Prov. I.3-4, p. 8). Fortune, for her part, resembles a gladiator who scorns a victory over an inferior opponent and seeks out instead the bravest men ("fortissimos") in order to try them with all her powers (De Prov. III.4, p. 1 7). A fearless young man may meet a lion's charge, but that contest of man against beast bears no comparison to the wrestling match between a strong man and ill fortune ("vir fortis cum fortuna mala"), which, Seneca insists, is a cosmic spectacle worthy of God's gaze (De Prov. II.7-9, p. 1o).

Like Seneca, Christian commentators on the Book of Job use the image of the wrestler to describe the hero engaged in spiritual struggle. ${ }^{28}$ As Barbara K. Lewalski has observed, both Origen (third century) and Saint John Chrysostom (fourth century) depict Job as an athlete in a theatrical wrestling match, championing the cause of God against Satan. ${ }^{29}$ Fulgentius calls Job an athlete in a mighty contest ("ille praecelsi atleta certaminis") and the overcomer of satanic force: "sataelica superator virtutis." 30 Saint Gregory the Great's influential Moralia in Job extends the image of the mighty wrestler and gladiator and uses it repeatedly both to unify his encyclopedic exposition of the text and to qualify the Book of Job as a heroic biblical poem.

At first Gregory emphasizes the image of the wrestler. Comment-

28. A persistent tradition numbered Seneca among the Christians in Nero's household and attributed to him correspondence with Saint Paul. See St. Jerome, "De viris illustribus," xii, PL 23, c629; C. Aubertin, Sénèque et Saint Paul (Paris: Didier, 1872).

29. Barbara K. Lewalski, Milton's Brief Epic: The Genre, Meaning, and Art of 'Paradise Regained' (Providence: Brown University Press, 1966), p. 22.

30. Fulgentius, De aetatibus mundi et hominis, in Opera, p. 142. 
ing on the opening lines of the book, which describe Job as a virtuous man, Gregory likens the listing of virtues to the common practice of storytellers who, in the narration of a wrestling match, first describe the bodies of the contestants:

Mos uero esse narrantium solet ut cum palaestrae certamen insinuant, prius luctantium membra describant quam latum ualidumque sit pectus, quam sanum, quam pleni tumeant lacerti, quam subterpositus uenter nec mole grauet, nec extenuatione debilitet. Vt cum prius aptos certamini artus ostenderint tunc demum magnae fortitudinis ictus narrent. Quia ergo athleta nostra contra diabolum fuerat certaturus, quasi ante arenae spectaculum, sacrae scriptor historiae in athleta hoc spiritales uirtutes enumerans, mentis membra describans ait. . . (I.iii.4, p. 27)

[But it is the custom of narrators, when a wrestling match is woven into the story, first to describe the limbs of the combatants, how broad and strong the chest, how sound, how full their muscles swelled, how the belly below neither clogged by its weight, nor weakened by its shrunken size, that when they have first shewn the limbs to be fit for the combat, they may then at length describe their bold and mighty strokes. Thus because our athlete was about to combat the devil, the writer of the sacred story, recounting as it were before the exhibition in the arena the spiritual merits in this athlete, describes the members of the soul.] (Vol. 1, p. 34)

Later, when Gregory comments on Job's successive tribulations, he again likens the hero's struggle to that of a wrestler in a theatrical contest:

Quotiens in arenae spectaculum fortis athleta descenderit, ii qui impares uiribus exsistunt uicissim se eius expugnationi subiciunt; et uno uicto, contra hunc protinus alter erigitur. Atque hoc subacto, alius subrogatur, ut luctantis uires quandoque molliores inueniant quas ipsa sua crebrescens uictoria fatigat; quatenus cum nouus quisque congreditur, is qui uinci uirium qualitate non ualet, personarum saltim mutatione superetur. Sic sic in hoc hominum angelorumque spectaculo beatus Iob fortis athleta prodiit, quantumque contra mutationes aduersantium ualeat continuatione indefessi roboris ostendit. (X.I. 1, p. 534)

[As of ten as a mighty wrestler is gone down into the arena of the lists, those who prove no match for him in strength by turns present themselves 
for the working of his overthrow, as fast as one is overcome another is directly raised up against him, and, he being subdued, another takes his place, that they may sooner or later find his strength in wrestling more yielding, in that his repeated victory by itself wears it out, so that as each fresh opponent comes to the encounter, he who cannot be overcome by the nature of their powers, may at least be got the better of by the changing of persons. Thus, then, in this theatre of men and angels, blessed Job proved himself a mighty wrestler, and how he prevailed against the charges of his adversaries, he shews by his continuance in unabated force.] (Vol. 1, p. 575)

Like Seneca in his description of the afflicted Sage, Gregory alternates between the images of the wrestler and the armed gladiator in characterizing Job's mental agon. Drawn into battle, Job meets the losses of his property, children, and health like enemies attacking him head-on: "quasi hostes contra faciem" (Preface, V. 1 , p. 16). He endures the words of his would-be consolers like foes attacking at his side: "quasi hostes ex latere." Defended by his shield, he vigilantly counters the swords of his attackers: "uenientibus gladiis uigilanter obuiauit." Armed with the swords and spears of love ("gladiis amoris," "amoris iacula") and defended by the shield of patience ("scutum patientiae," "patientiae clypeo"), the mind of the holy man draws strength to sustain his injuries: "ad perferenda mala sumit fortitudinem" (VIII.ii.2, p. 382). In the war of tribulation, saints like Job sometimes employ the shield of patience, at other times the darts of teaching, and thus display a marvelous skill of virtue that bravely endures exterior calamities and wisely counters perverse thoughts within themselves: "peruersa intus sapienter doceant" (III. xxi.39, p. 140). Thus our hero Job ("bellator noster"), wounded in body, stands erect in the fortress of his mind: "erectus intrinsecus munimine permanet mentis" (III.x.1 7 , p. 126). Conquering himself through patience, he possesses his own soul, the inner victory that renders him invincible in adversity: "sese ad contraria inuictum parat" (V.xvi.33, p. 241).

Gregory's allegorical use of traditionally epic images betrays a clear Stoic influence. In his ninth-century biography of Gregory, John the Deacon calls him "arte philosophus," 31 and F. Holmes Dudden

31. John the Deacon, Vita I.i, PL 75, c63. 
rightly considers that title an indication of Gregory's mastery of moral philosophy. ${ }^{32}$ Gregory himself observes that although Christ first chose the uneducated to confound the wise, he afterwards called philosophers as well to discipleship (XXXIII.xviii.34, p. 1705). As a Christian philosopher, Gregory makes what G. R. Evans has called an innovative and remarkably "confident use ... of his borrowed philosophical ideas," introducing Stoic and Neoplatonic teachings into biblical contexts and altering their fundamental terms in the process. ${ }^{33}$

In the Senecan narrative, as we have seen, a personified Fortune, who is virtually identical with God (Deus mundus), puts the Wise Man to the test. When Gregory adopts the Stoic images of the wrestler and the gladiator in his exposition of Job, the part of the Adversary is redefined so that, as Villy Sørensen puts it, "fortuna in Seneca corresponds to Satan in Job." 34 The resemblances are readily apparent. Both Fortune and Satan act to deprive the Virtuous Man of exterior goods and measure their blows according to the moral stature of their human opponent. Both are unable to affect the inner disposition of the hero, whose fortitude displays itself in mental constancy (constantia mentis) and who grows in spiritual goods, especially self-knowledge, as a result of material loss.

There are, however, significant differences as well. When confronted with the problem of the innocent sufferer, Seneca defines the issue as a purely subjective one, dependent on the rational response of the Sage. Correctly perceived, nothing is evil, and "no evil can befall a good man" (p. 7) (De Prov. II. 1: "Nihil accidere bono viro mali potest"). For Gregory and for the author of Job, however, evil is objective and the question centers on justice, God's and man's. Gregory, meditating on Christ and Job, insists that the just do suffer, but that that affliction in no way compromises the justice of God. Indeed, everything we suffer is just: "iusta sunt cuncta quae patimur" (II.xviii.31, p. 79).

32. F. Holmes Dudden, Gregory the Great: His Place in History and Thought, vol. 1 (New York: Russell and Russell, 1905,1967 ), p. 76.

33. G. R. Evans, The Thought of Gregory the Great (Cambridge: Cambridge University Press, 1986), p. 65.

34. Villy Sorensen, Seneca: The Humanist at the Court of Nero, trans. W. Glyn Jones (Edinburgh: Canongate; Chicago: University of Chicago Press, 1984), p. 200. 
Gregory finds a dramatic answer to this apparent self-contradiction in the person of the devil and his malicious intent. Inspired by such New Testament passages as 1 Peter 5:8, Gregory represents the Joban Adversary no longer as an actual member of the heavenly court, as the Book of Job implies, but rather as personified Evil, the Old Enemy of both God and humankind. ${ }^{35}$ The devil exercises his terrible force against Job, but his real target is God; Job simply occupies the middleground of the conflict between God and the devil: "Inter Deum itaque et diabolum beatus Iob in medio materia certaminis fuit" (Preface III.8, p. 14). By driving a wedge between God and the scriptural Adversary and depicting the conflict between them as vehement and cosmic in proportion, Gregory avoids the problem of attributing injustice to God.

At the same time, as Carole Straw observes, Gregory avoids the Manichaean position of two gods, one evil and one good, by pointedly affirming "the omnipotence of God and the unity of the divine dispensation." 36 The devil has a kind of contract with God which allows him a limited freedom to gratify his own perverse desire to torment others. God, for his part, uses the devil's attacks to accomplish an entirely different, benevolent result. Thus the divine plan is implemented even as it is opposed: "Sic sic diuinum consilium dum deuitatur, impletur" (VI.xviii.29, p. 305). As Straw puts it, the devil paradoxically " 'fulfills' God's will by his very 'resistance' to it," and "the anger and evil of the devil bring to completion the kindness and mercy of God" (p. 62). The Lord therefore permits his brave soldier Job to be attacked again and again only to increase Job's glory as a conquerer in proportion to the repeated assaults of the defeated enemy (II.xi.19, pp. 71-72).

Pitted against such a malignant, invisible enemy, Job achieves a heroic stature greater than that of the Stoic Sage opposed to mundane Misfortune. Indeed, Job's passionate outcry becomes for Gregory the measure of his true fortitude. When Gregory comments upon Job's lamentation, he cites the Aristotelian doctrine of the Golden

35. See Neil Forsyth, The Old Enemy: Satan and the Combat Myth (Princeton: Princeton University Press, 1987), esp. pp. 107-23, for an excellent discussion of the changing biblical image of the adversarius.

36. Carole Straw, Gregory the Great: Perfection in Imperfection (Berkeley: University of California Press, 1988 ), p. 62. 
Mean to refute the Stoic notion that true fortitude consists in apatheia, the absence of feeling. Job, he says, observes the rule of true philosophy (II.xvi.29, p. 77: "uerae philosophiae regulam tenuit"), which holds that the measure of true virtue is neither hardness of heart not irrational grief, but rather the submission of sorrow to a reason enlightened by faith (II.xvi.28, p. 77). Indeed, as we shall see, Gregory understands the felt experience of suffering, an actual share in Christ's passion and death, to be a necessary prerequisite for the attainment of true wisdom.

Gregory's exegetical expansion of the Senecan images of athlete and warrior is warranted by both Scripture itself and previous Christian treatments of Job. ${ }^{37}$ A key verse in the Book of Job terms the earthly life of humankind a warfare: "Militia est vita hominis super terram" (Job 7:1), and a variety of New Testament texts (1 Corinth. 9:7, Phil. 2:25, 2 Tim. 2:3-4, Phil. 1:2, Eph. 6:11-17) describe the Christian as a soldier of Christ. Interpretation through concordance, moreover, inspired exegetes to associate martial images with other biblical passages that were read in parallel with Job. ${ }^{38}$

Cassiodorus (c. A.D. 480-575), for instance, reads Psalm 37 as an instance of ethopoeia in which David impersonates Job as the unconquered soldier of Christ. ${ }^{39}$ The psalm, Cassiodorus observes, voices sentiments similar to those found in the Book of Job and has a similar structure, moving from a two-part narrative of affliction in body and soul to an expression of healing consolation ("consolatio medicinae salutaris") and trust in God, and ending with a praise of God as Savior. David playing the part of Job ("Iob este Dauidicus") becomes strong and triumphant in his spiritual mastery of misfortune (p. 353). Thus Job, the archetypal soldier of Christ and victor over mortal life, prefigures both the strife and the victory of all the Lord's warriors: "Domini milites" (p. 353).

Prudentius too takes the Book of Job as a key point of reference when he interprets the Abraham story in Genesis allegorically as a

37. Lewalski cites a variety of Christian commentators, including Prosper, Methodius, Tertullian, Cassiodorus, and Prudentius (Milton's Brief Epic, p. 22).

38. Explicit biblical references to Job occur in Ezechiel $14: 14$, Tobit 2:15, and James 5:11.

39. Cassiodorus, Expositio Psalmorum, ed. M. Adriaen, CCSL 97 (Turnhout: Brepols, 1958), p. 343. Subsequent citations are parenthetical by page. 
spiritual battle between personified virtues and vices. Indeed, Prudentius' Psychomachia (A.D. 405) stands as the most important literary precedent for both Gregory's conversion of authoritative biblical metaphor into bellicose allegory and his exegetical use of epic materials. In Prudentius' poem, Long-Suffering ("Patientia") endures the vicious attack of Wrath ("Ira"). Unable to hurt Long-Suffering, who is protected by a corselet, Wrath exhausts her strength in fury and finally slays herself. Observing that Wrath is her own enemy, the invincible Long-Suffering walks unharmed through the battlefield accompanied by a noble man, her earthly exemplification, Job. ${ }^{40}$ Prudentius goes on to observe that all the other Virtues rely upon Long-Suffering, because there is by definition no virtus without the strength ("fortitudo") represented in patient endurance.

In his depiction of battle and especially in his portrayal of Wrath ("Ira"), Prudentius uses Virgilian language, echoing in particular Book 12 of the Aeneid. As Macklin Smith phrases it, "Prudentius . . . uses epic to compose allegory." ${ }^{41}$ The procedure deliteralizes pagan epic, exposing at once the falsity of its letter and the heroic ideal to which it gives expression and revealing the truth of its Christian allegory as an authentically "other" form of heroism.

Gregory's procedure in the Moralia is similar. To establish the Book of Job as a heroic work, Gregory first calls attention to the epic (especially Virgilian) question of the pious sufferer that informs the Book: "cur tot flagella pertulit" (Preface III.7, p. 12). Gregory then elaborates an allegory of Job that uses the battle scenes and athletic games of classical epic; he incorporates the heroic topic of fortitudo et sapientia in characterizing Job as a soldier of Christ, a miles Christi; and he consciously rejects a grand style exposition of Job, refusing to submit heavenly words to the rules of Donatus (Ad Leandrum 5, p. 7) and choosing instead the humble style (sermo humilis) of a Christian teacher. Epic thus becomes the allegory of Scripture, and epic truth (as the Otherness of epic) becomes identified with the biblical Word itself, understood typologically with reference to Christ, the Church, and the individual Christian.

40. I use the Loeb Classical Library edition of the Psychomachia in Prudentius, vol. 1, trans. H. J. Thomson (Cambridge: Harvard University Press, 1949, 1969).

41. Macklin Smith, Prudentius' Psychomachia: A Reexamination (Princeton: Princeton University Press, 1976), p. 105. 
The primary Christological reference, according to which Job's sufferings in body and soul foreshadow the redemptive passion of Christ, contributes more than any other cause to the Gregorian redefinition of heroic fortitude. Gregory observes that the name Job translates into Latin as dolens, so that the Redeemer's suffering might be signified by both Job's name and his wounds: "per eius et nomen et uulnera" (VI.I. 1, p. 284). Job's bodily afflictions from head to foot also prefigure the persecutions endured by the members of Christ's Mystical Body, the Church.

In this context fortitude no longer qualifies the public action of a citizen-soldier seeking fama; it marks instead a person's heroic acceptance of God's Will in the form of the cross. Just as danger, especially the danger of death, occasions the fearlessness of natural fortitude, the boldness of divine fortitude originates in the Fear of the Lord (Timor Dei), the gift of the Spirit that strengthens the mind to regard the loss of temporal things as nothing in comparison to the loss of God Himself (see V.xvi.33, p. 241). In this way, Gregory avers, fear gives rise to fortitude, fortitude to patience, and patience to perfection.

\section{The Hero's Sapience}

The prudent man, according to Aristotle, is "able to deliberate well about what is good and advantageous for himself . . as a means to the good life in general." ${ }^{22}$ That pragmatic ability, in turn, depends upon his self-knowledge (including the knowledge of his own ignorance) and his knowledge of ultimate causes. Thus, as we have seen, the Neoplatonists considered it the greatest wisdom for a person to recall his true spiritual homeland and choose a course of earthly detachment in keeping with his soul's high destiny.

For Saint Paul, however, true wisdom is not the human achievement of a "wise man" (sapiens) exercising his understanding; rather, true wisdom is revealed in the person of Christ who is "the power of God and the wisdom of God" (i Corinth. 1:24). According to Paul, this divine wisdom, which glories in the cross, seems foolishness to 
the Greek philosophers, and one attains to it not by one's own rational powers but by having instead "the mind of Christ" ( 1 Corinth. 2:16). Indeed, one can reason rightly about life's choices only if one first believes, if faith enlightens the ratio.

Gregory follows Saint Paul in making the sacred scriptures, as the revealed Word of God, the standard for a true moral philosophy. According to Gregory, we come to fulfill the Delphic oracle, to know ourselves, through reading the Bible: "Holy Writ is set before the eyes of the mind like a kind of mirror, that we may see our inward face in it; for therein we learn the deformities; therein we learn the beauties that we possess" (vol. 1, p. 67) (II.I. 1, p. 59: "Scriptura sacra mentis oculis quasi quoddam speculum opponitur, ut interna nostra facies in ipsa uideatur"). As Gregory's dedicatory letter to Leander of Seville makes clear, he himself reads the Book of Job as a personal mirror. Sick for over a year with digestive ailments and burdened with pastoral responsibilities, Gregory muses over his commentary on Job: "And perchance it was this that Divine Providence designed, that I, a stricken one, should set forth Job stricken, and that by these scourges I should the more perfectly enter into the feelings of one that was scourged" (vol. 1, p. 1o) (Ad Leandrum 5, p. 6: "Et fortasse hoc diuinae prouidentiae consilium fuit, ut percussum Iob percussus exponerem, et flagellati mentem melius per flagella sentirem"). ${ }^{43}$

For Gregory, as for the Stoics and Neoplatonists, self-knowledge is fundamental to wisdom. According to the Gregorian understanding, however, human beings are lacking in self-knowledge, in wisdom, not because of a Platonic fall into bodily and sensory experience, but because of the original sin that separated humankind on earth from intimacy with God and thus precipitated a darkening of human nature in both body and soul (IX.xxxiii.51, p. 492). Having lost the light of invisible things that transfigured the visible things of paradise (V.xxxiv.61, p. 261), and being thus expelled from paradisal joys, humankind immerses itself in the love of exterior things that can be seen and touched. The soul is then blinded in its inner spiritual vision to the extent that it is distracted by exterior impressions, clouded with outward images: "tantoque ab interna speculatione

43. For biographical information, see Jeffrey Richards, Consul of God: The Life and Times of Gregory the Great (London and Boston: Routledge and Kegan Paul, $1980)$. 
caecata est quanto foras deformiter sparsa" (V.xxxiv.61, p. 261). Only with great efforts does a person turn aside from his own bodily appearance and direct his soul to the knowledge of itself ("ad cognitionem suam") as a spiritual entity. Thinking of himself in spiritual terms, he can prepare a way for himself toward the consideration of the eternal Good: "ut semetipsam sine corporea imagine cogitet et cogitando se, uiam sibi usque ad considerandam aeternitatis substantiam paret."

God Himself aids humankind in its recovery of self-knowledge in various ways. First of all, the promptings of conscience, as the inner voice of God, recall the soul to the knowledge of itself (XVI.xxviii.35, p. 819: "ad cognitionem sui anima subtilius reuocetur") and allow it to behold within itself its own hidden judge. The elect thus remember that they are created in the image and likeness of the Creator and strive to live in accord with that perceived similarity: "ad auctoris sui imaginem ac similitudinem si condita meminit, et iuxta perceptae similitudinis ordinem incedit" (XXX.xvii.56, p. 1529).

That divine image and likeness gains a unique visible expression in the Incarnate God, in the Word-Made-Flesh. Scripture therefore allows for a typological self-knowledge. One's own humanity emerges in conformity with the pattern of Christ's life as an imitatio, even as Job, the Old Testament "homo verus," foreshadows the Christ who is True God and True Man. Gregory's emphasis on selfknowledge thus leads him to characterize Job according to a double image. As Lawrence Besserman observes, Job emerges "as a patient Christian saint" in Gregory's historical and moral readings; as a "type of Christ" in Gregory's allegory. ${ }^{14}$

Gregory's Christological approach to Job's suffering provides a basis for his redefinition of not only fortitudo but also sapientia as heroic virtues. Suffering is for Gregory both the means and the expression of true wisdom because, as Straw phrases it, "through life in the body, man comes to know himself and his Creator, to understand what it means to be human and, by contrast, to glimpse something more of divine perfection." 45 That comparative self-knowledge,

44. Lawrence L. Besserman, The Legend of Job in the Middle Ages (Cambridge: Harvard University Press, 1979), p. 55.

45. Straw, Gregory the Great, p. 127. 
which "finds its center in man's carnal existence," depends on a number of characteristically Gregorian juxtapositions: Mutability and Immutability, Way and Destination, Body and Soul, Emotion and Reason. ${ }^{46}$

As Straw puts it, in Gregory's view the "sorrows of mutability come from Adam's rejection of stability in God." 47 Mutability, in short, marks our postlapsarian condition, making it a continuous, miserable alternation of prosperity and adversity, good times and bad: "mortalitatis lapsum per prospera et aduersa uariantem quam despicabilem" (IV.xii.23, p. 179). Thus Job, meditating on how human hope is raised by prosperous circumstances only to be dashed by troubles, recalls with regret the changeless state of happiness that humankind could have retained in paradise. Having lost its standing position in the cosmos through a falling away from God, humankind experiences time itself as slippery ("quasi lubrico temporalitatis") and suffers both exterior and interior change whenever it tries to raise itself up to better works: "Quam tamen mutabilitatem non solum exterius, sed interius quoque homo patitur, dum ad meliora exsurgere opera conatur" (XI.1.68, p. 625).

Thus life itself is a constant trial. The striving person discovers in himself only instability and the tendency to change, so much so that, despite his best intentions, he falls again and again and lacks the strength to maintain a contemplative stance: "vult in contemplatione stare, sed non ualet" (VIII.vi.8, p. 386). In this way he remembers what he has lost, the paradisal strength of contemplation and the firmness of original fortitude: "uim contemplationis perdidit, robur conditae fortitudinis amisit" (IX.xxxiii.5o, p. 491). Only by embracing in humble obedience the trial and suffering that belong to fallen humanity does a person grasp and reconquer, albeit to a limited extent, his own unfallen condition and its original constancy rooted in God. He wills what God wills. Unlike the constantia mentis of the Stoics, however, Gregorian wisdom (to use Straw's phrase) “demands not apatheia, but passio" (p. 199), the willingness to suffer, the firm "yes" to one's own experience of weakness.

The changing nature of things, the painful instability of the fallen

46. Ibid.

47. Ibid., p. 109. 
world, helps a person to remember that he is in motion himself, a pilgrim on a journey, an exile from his true homeland. Confused by the blindness of exile due to original sin, a person might mistakenly believe the place of exile to be his Fatherland: "ut exsilium patriam crederet" (VII.ii.2, p. 335). ${ }^{48}$ Frequent perturbations, however, prevent us from loving the way instead of the destination, and the elect live out of the consciousness that the present life is a road leading to the Fatherland: "uia quippe est vita praesens, qua ad patriam tendimus" (XXIII.xxiv.47, p. 1 1 79). The wayfarer does not desire to remain with transitory things but to arrive at eternal things (XV.lvii.68, p. 792). Similarly, the pilgrim people of God experience heartfelt longing for the supernal Fatherland (XVIII.xxx.48, p. 916 ). Indeed, it is the habit of the just to consider the transitoriness of the present life in order to perceive from the flight of passing external things the things that endure within us: "quae manentia intus" (Preface to Book XII, p. 628).

Corporeal mutability, even more than the exterior blows of fortune, teaches the Christian Wise Man to consider what is immutable in himself. Gregory therefore describes Job as a philosopher who purposely sits upon a dunghill in order to consider in that physical context his own bodily decay: "ut considerationem fragilitatis suae etiam ex circumstantibus traheret" (III.vii. 1 o, p. 1 20). Job placed his ulcerous body there, Gregory says, in order to remind himself how quickly the body returns to stench: "quod festine corpus ad fetorem rediret."

Such a bodily positioning frees the mind and gives the body an instrumental share in the redemption of the soul. Thus, as an exemplum of the wise man (consiliator), a sorrowing Job (dolens) hastens in thought from temporal to eternal things and, although still in the world, mentally passes beyond it: "mente iam extra mundum surgit" (I.xxv.34, p. 44). To do so is to share paradoxically in the immutability of the angelic nature through the awareness of one's own mutability (V.xxxviii.68, p. 267). Unable to contemplate God steadfastly and directly like the angels, a human being can nonetheless consider the fragility of his own body and thus, loosened from its chain, rise up in spirit to the consideration of the God who is Spirit (IV.xxxiv.68, p. 213 ).

48. See also I.xxv.34, p. 43 . 
Gregory's own exegetical approach to the Book of Job exemplifies this kind of mental movement from the slippery body of the literal text to its abiding spiritual meaning. If we understand Job's words correctly, his superficially blasphemous outcry ("eius maledictio") actually expresses the right judgment of a man not stirred by wrath but rather tranquil with true teaching: "non est ira commoti sed doctrina tranquilli" (IV.i.3, p. 165). Outwardly ("foras") he speaks in sorrow, but allegorically ("intus") he administers the power of a healing medicine to the wounded: "uulneratis intus ostendit uirtutem medicaminis" (IV.i.3, p. 166). Through a polysemous discourse Job thus combines in his person both the instructed and the instructor, the patient and the physician, the Boethius who weeps and the Philosophia who consoles.

\section{Job's Boethian Heroism}

Using epic to construct his Joban allegory, Gregory presents Job as a warrior whose fortitudo surpasses that of his Iliadic counterparts, as a philosophical traveler whose sapientia exceeds that of Odysseus on his homeward journey. Job's human nature, perfected in wisdom and power through suffering, reflects Christ's own divine humanity and far surpasses in heroic virtue the excellence of even an allegorized Aeneas. The biblical hero who emerges from Gregory's Moralia grows in self-knowledge through his trials and finally comes face to face with a God like the one to whom Lady Philosophy directs her pupil Boethius. As G. R. Evans observes, Gregory's God, like that of The Consolation of Philosophy, is "one immortal, supremely good, tranquil and unchanging, supremely happy and reasonable being" who governs the world providentially according to a wise and omnipotent plan. ${ }^{49}$

It is likely that Gregory knew Boethius' Consolation and was inspired by it in his commentary on Job. Saint Thomas Aquinas, following both Maimonides and Gregory, was keenly aware of the

49. Evans, Thought of Gregory the Great, p. 57. Evans calls attention to the quest of Christian apologists like Hilary of Poitiers (c. 315-67) who sought "Scriptural evidence that the divine attributes were in fact those felt to be appropriate on philosophical grounds to the Supreme Being" (p. 56). 
structural and thematic parallels between the Book of Job and Boethius' Consolation and called attention to them in his thirteenthcentury commentary. ${ }^{50}$ Indeed, as Aquinas interprets it, Job is virtually a biblical Consolation. The two books, one scriptural and therefore theological, the other philosophical, teach the same truth (forma tractatus) and employ a similar narrative and pedagogical method (forma tractandi).

Aquinas' Prologue to his Joban expositio begins with a refutation of early philosophers, such as Democritus and Empedocles, who attributed the majority of occurrences to chance. Aquinas cites "the diligence of later philosophers," who have argued "that natural things are controlled by providence," because the regular "movement of heaven and of the stars," as well as other predictable natural effects, point to the governance of things "by some supereminent intelligence." 51 Aquinas then raises the key issue (also central to Boethius' Consolation) whether "human affairs" are similarly governed "by some providence or superior ordinance" (pp. 67-68). The "whole intention" of the Book of Job is, he says, to show "through plausible arguments that human affairs are ruled by divine providence" (p. 68). Since the causeless affliction of the just "seems to undermine totally the foundation of providence," the Book of Job purposely raises and resolves the quaestio through a test case: "the many grave afflictions of a certain man, perfect in every virtue, named Job" (p. 68).

Job, like Boethius, is an innocent sufferer. When Job bitterly laments the loss of his property, his children, his health, and his good name, he lays bare his wound in the sight of God and men. Aquinas immediately draws the parallel: "So too Boethius in the beginning of On the Consolation of Philosophy disclosed his sadness to show how to mitigate it with reason, and so Job disclosed his sadness by speaking" (p. 10o).

Like Gregory, who insists that Job observed "the rule of true philosophy" ("uerae philosophiae regulam") in his outcry by keeping a balance between his emotion and his reason, Aquinas attributes to

50. For a discussion of Aquinas' debt to Maimonides and Albert the Great see Beryl Smalley, The Study of the Bible in the Middle Ages (Oxford: Blackwell, 1952; Notre Dame: University of Notre Dame Press, 1964), p. 302.

51. Thomas Aquinas, Literal Exposition on Job: A Scriptural Commentary Concerning Providence, trans. Anthony Damico, ed. Martin D. Yaffe (Atlanta, Ga.: Scholars Press, 1989), p. 67. Subsequent citations are parenthetical by page. 
Job "such moderate sadness that it was subject to reason" (p. 87). Following Gregory, Aquinas rejects the opinion of the Stoics, who said "that external goods are not the goods of man and that there could be no sadness in the spirit of the wise man over their loss." In opposition to them, he endorses the view of the Peripatetics, who held that "external goods are indeed a kind of goods for man," and therefore "the wise man is moderately saddened at the loss of external goods." As Aquinas observes, "reason cannot remove the condition of nature," and the "sensual nature" of human beings is naturally delighted by pleasant and useful things, "pained and saddened over harmful things" (p. 99). ${ }^{52}$

Whereas Gregory distinguishes between the literal and the allegorical levels of Job's words, between what is exposed to the outside ("foras") and hidden within ("intus"), Aquinas differentiates between the various levels of Job's psychological makeup. In his emotional outpouring, Job "speaks in the character of his sensual side, expressing his feeling, which has room only for the present corporeal goods and evils" (p. 1o $)$ ). Thus Job sometimes enacts "the role of an afflicted man" (p. 183), "the role of an embittered man" (p. 184). While allowing his sensual nature its due, however, Job still affirms and assents to the divine will in his rational nature, combining the steadfast patience of his mind and will with human feelings of sadness appropriate to the terrible losses he has experienced (see p. 140).

To be sure, powerful feelings can subvert the reason, even as emotional language can impair one's ability to think objectively. When Gregory and Aquinas treat that danger in their analysis of Job's rebuke of his despairing wife, the exchange between the couple becomes a biblical analogue to Lady Philosophy's dismissal of the strumpet Muses. ${ }^{53}$ Job's unnamed wife speaks only once, encouraging her afflicted husband to curse God and die: "Benedic Deo et morere" (Job 2:9) ${ }^{54}$ In that single enigmatic utterance, the commen-

52. Aquinas refers again and again to the opposed positions of the Stoics and Peripatetics on the grief of the Wise Man. See also pp. 115,139 , and 140.

53. For a discussion of this passage from the perspective of medieval mysogyny see my "Job's Wife, Walter's Wife, and the Wife of Bath," in Old Testament Women in Western Literature, ed. Raymond-Jean Frontain and Jan Wojcik (Conway: University of Central Arkansas Press, 1991), pp. 92-107.

54. The Latin euphemism, which substitutes "bless" for "curse," reflects the original Hebrew use of euphemism as a standard practice in this and similarly blasphemous passages. 
tators find a reenactment of Eve's temptation of Adam: "uerba sua Eua repetit" (Moralia III.viii.14, p. 123). When Job's wife at the instigation of Satan leads Job into despair, she not only speaks words of a bad persuasion (III.viii.14, p. 123 : "male suadentis uerba"); she also seduces Job with blandishments (III.viii.13, p. 122: "per uerba blandiens loquitur") and, appealing to his sensuality, pierces his heart with the force of love: "uis amoris cor perforat." Job, however, resists her Siren-like temptation to suicide. Indeed, when he corrects and instructs his erring wife, he offers a model for the exegetes who either allegorize Job's own malediction (when, for example, he literally curses the day of his birth) as an articulation of dogma, or consider it the expression of only his lower, sensual nature, his carnal, feminine self, not his whole person. ${ }^{55}$

Job's carnal self, exteriorized in his weeping wife, can find no meaning in his suffering. As Aquinas observes, however, when Job speaks out of his rational nature "in the manner of a debater" (p. 156), he answers his heretical would-be consolers, who interpret misfortune only as a divine punishment for wrongdoing, by pointing to three possible causes for affliction: to protect people by restraining the malice of the wicked, to manifest the exemplary virtue of the good, and "to punish sinners" (p. 156). The second reason, as Aquinas insists, applies to Job: "This was the cause of blessed Job's adversitythat his virtue should be made manifest to all" (p. 83). God tests Job by permitting Satan to test him, not that God might know "what kind of man he is, but in order to have others know him and so that the man may know himself" (p. 153). When Job, therefore, stripped of his earthly goods, reflects on his own nakedness at birth and at death

55. According to Gregory, the word "woman" (mulier) in Scripture either literally designates a member of the female sex or figuratively names weakness: "In sacro eloquio mulier aut pro sexu ponitur aut pro infirmitate" (XI.xlix.65, p. 623). Gregory goes on to contrast the discretion of a strong man ("vir fortis") with the weak, indiscreet mind ("mens infirma uel indiscreta") of a woman. Elsewhere (Moralia XXX.xvi.54, p. 1528) Gregory interprets the creation of Eve during the sleep of Adam in a way that associates woman's nature with a man's emotional sphere, his unconscious, his "animal part." A r.i'n's reason should rule his emotions, Gregory says, even as a man governs his wife. For a similar gendered distinction between the higher and lower parts of the soul see Cicero, Tusculan Disputations, II.xxi, pp. 200-205. See my "Translating Job as Female," forthcoming in Translation Theory and Practice in the Middle Ages, ed. Jeanette Beer (Kalamazoo, Mich.: Medieval Institute Publications), for a discussion of Job and gender symbolism. 
(Job 1:21), he knows himself as a creature radically dependent in prosperity and adversity upon "the judgment of divine providence" (p. 89). Like the Stoics, Job "demonstrate[s] rationally" (p. 88) the right of God to dispossess him of goods and the injustice of human complaint. ${ }^{56}$

Rational argument alone, however, cannot resolve the quaestio of divine justice and providence-especially since Job's affliction does not manifest his virtue to his companions, but rather compromises it in their eyes. Eliphaz, Bildad, Zophar, and Elihu continue to defend God's justice by blaming Job himself for his troubles. In answer Job posits "another life in which just men are rewarded and evil men are punished" (p. 194) and prophetically declares his faith in eternal life (p. 224), in the resurrection of the dead (pp. 230, 270), and in the resurrected Christ as his Redeemer (pp. 268-69): "For I know that my Redeemer liveth" (Job 19:25).

Aquinas, therefore, reconstructs the Joban disputatio about divine providence on three levels of response correspondent to the threefold Boethian definition of human nature. Job responds as a sensual, mortal being with tearful lamentation, with the longing for death. As a rational being, he resigns himself virtuously to God's will. As a besouled, immortal being, he looks forward to a heavenly homecoming. The last and highest level of response, which makes Job an Old Testament Christian, has, as Aquinas notes, its closest analogue in the teaching of the Neoplatonists:

For the Platonists have posited that the souls of men were derived from the souls of stars. Hence, when human souls preserve their dignity by living according to reason, they return to the splendor of the stars whence they have descended. Hence, one reads in the Dream of Scipio that "rulers and preservers" of cities "who have set out from here," namely, from heaven, "return there." In this work, too, the author gives one to understand that he was not placing the ultimate remuneration for virtue in temporal goods but in spiritual goods after this life. (p. 406)

56. Job's speech, "The Lord gave, and the Lord hath taken away" (Job 1:21), provides a biblical parallel to the speech of the Cynic philosopher Demetrius, quoted approvingly by Seneca in De Prov. V.5-6, p. 37: "I shall make no protest against your taking back what once you gave." As G. R. Evans notes (Thought of Gregory the Great, p. 31), Gregory the Great actually uses a formal syllogism to demonstrate logically the justice of human suffering (II.xviii.31, p. 79). 
Whereas Gregory emphasizes that only a vir, heroic in wisdom and fortitude, can mirror the wisdom and power of God displayed in his providential plan, Aquinas stresses that only a homo who has fully realized his own hierarchical humanity in its sensual, rational, and divine dimensions can meet the God of Providence. That epiphanic encounter, like the concluding book of Boethius' Consolation, underscores at once the greatness of human nature and the radical insufficiency of human wisdom "to comprehend the truth of divine providence" (p. 415). The homo who is a hero (vir), however, can sustain the knowledge of his own limits and thus end his life's odyssey in a return home, both to himself and to God.

Indeed, the Christian hero is, by definition, at once an authentic human being and a saint. In an etymological discussion that succinctly summarizes the historical development of the idea of heroism from antiquity to the Middle Ages, John of Salisbury first derives the Latin adjective verum ("true") from the Greek word heron ("heroic"), meaning "secure and stable or certain and clear" and used to describe the mythological demigods who "attained a state of security and stability by being associated with the gods in ancient mythology." ${ }^{57} \mathrm{He}$ then goes on to translate both terms, verum and heron, with "a catholic word," saint. "Confirmed' in virtue or glory," in fortitude and wisdom, the Christian saint achieves through grace a Boethian transfer "from this world's inconstancy and emptiness to the glory of true certainty and security," which is found in God alone. Such a saint, the commentaries aver, was Job.

57. John of Salisbury, The Metalogicon: A Twelfth-Century Defense of the Verbal and Logical Arts of the Trivium, trans. Daniel D. McGarry (Berkeley: University of California Press, 1955), 4.34, p. 255. 